Prepared in cooperation with the

Manhasset-Lakeville Water District, Nassat County Department of Public Works,

New York State Department of Environmental Conservation, Port Washington Water District,

Sands Point Water Department, Suffolk County Department of Health Services,

Suffolk Gounty Water Authority, Town of North Hempstead, Town of Shelter Island, and

Water Authority of Great Neck North

Water-Table and Potentiometric-Sturface Altitudes in the Upper Glacial, Magothy, and Lloyd Aquifers

of Long Island, New York, April-May 2016

Pamphlet to accompany

Scientific Investigations Map 3398

U.S. Department of the Interior

U.S. Geological Survey 
Cover photo: Composite of U.S. Geological Survey Landsat 8 imagery from 0ctober 27 and November 21, 2017, showing Long Island, New York. 


\section{Water-Table and Potentiometric-Surface Altitudes in the Upper Glacial, Magothy, and Lloyd Aquifers of Long Island, New York, April-May 2016}

By Michael D. Como, Jason S. Finkelstein, Simonette L. Rivera, Jack Monti, Jr., and Ronald Busciolano

Prepared in cooperation with the

Manhasset-Lakeville Water District

Nassau County Department of Public Works

New York State Department of Environmental Conservation

Port Washington Water District

Sands Point Water Department

Suffolk County Department of Health Services

Suffolk County Water Authority

Town of North Hempstead

Town of Shelter Island

Water Authority of Great Neck North

Pamphlet to accompany

Scientific Investigations Map 3398 


\section{U.S. Department of the Interior \\ RYAN K. ZINKE, Secretary}

\section{U.S. Geological Survey James F. Reilly II, Director}

\section{U.S. Geological Survey, Reston, Virginia: 2018}

For more information on the USGS - the Federal source for science about the Earth, its natural and living resources, natural hazards, and the environment-visit https://www.usgs.gov or call 1-888-ASK-USGS.

For an overview of USGS information products, including maps, imagery, and publications, visit https://store.usgs.gov.

Any use of trade, firm, or product names is for descriptive purposes only and does not imply endorsement by the U.S. Government.

Although this information product, for the most part, is in the public domain, it also may contain copyrighted materials as noted in the text. Permission to reproduce copyrighted items must be secured from the copyright owner.

Suggested citation:

Como, M.D., Finkelstein, J.S., Rivera, S.L., Monti, Jack, Jr., and Busciolano, Ronald, 2018, Water-table and potentiometric-surface altitudes in the upper glacial, Magothy, and Lloyd aquifers of Long Island, New York, April-May 2016: U.S. Geological Survey Scientific Investigations Map 3398, 4 sheets, scale 1:125,000, 5-p. pamphlet, https://doi.org/10.3133/sim3398.

ISSN 2329-132X (online) 


\section{Contents}

Sheet 1_Upper Glacial and Shallow Magothy Aquifers (Water Table) ...........................................1

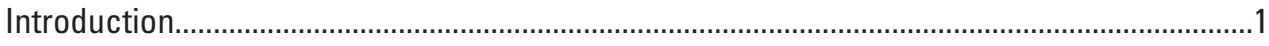

Upper Glacial and Shallow Magothy Aquifers (Water Table) .....................................................

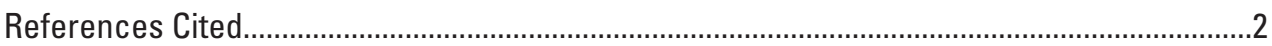

Sheet 2 - Potentiometric Surface in the Magothy and Jameco Aquifers ........................................2

References Cited ...........................................................................................................

Sheet 3-Potentiometric Surface in the Lloyd and North Shore Aquifers .......................................

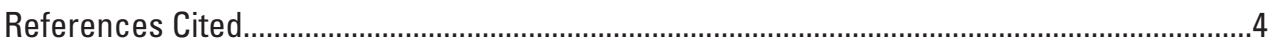

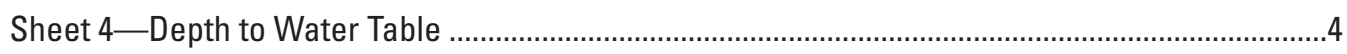

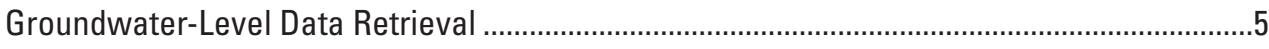

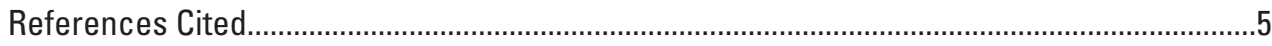




\title{
Water-Table and Potentiometric-Surface Altitudes in the Upper Glacial, Magothy, and Lloyd Aquifers of Long Island, New York, April-May 2016
}

\author{
By Michael D. Como, Jason S. Finkelstein, Simonette L. Rivera, Jack Monti, Jr., and Ronald Busciolano
}

\section{Sheet 1-Upper Glacial and Shallow Magothy Aquifers (Water Table)}

\section{Introduction}

The U.S. Geological Survey (USGS), in cooperation with State and local agencies, systematically collects groundwater data at varying measurement frequencies to monitor the hydrologic conditions on Long Island, New York. Each year during April and May, the USGS completes a synoptic survey of water levels to define the spatial distribution of the water table and potentiometric surfaces within the three main water-bearing units underlying Long Island - the upper glacial, Magothy, and Lloyd aquifers (Smolensky and others, 1990) — and the hydraulically connected Jameco (Soren, 1971) and North Shore aquifers (Stumm, 2001). These data and the maps constructed from them are commonly used in studies of the hydrology of Long Island and are used by water managers and suppliers for aquifer management and planning purposes.

Water-level measurements made in 424 monitoring wells (observation and supply wells), 13 streamgages, and 2 lake gages across Long Island during April-May 2016 were used to prepare the maps in this report (Finkelstein and Como, 2018). Groundwater measurements were made by the wetted-tape or electric-tape method to the nearest hundredth of a foot. Contours of water-table and potentiometric-surface altitudes were created using the groundwater measurements. The water-table contours were interpreted using water-level data collected from 275 observation wells and 1 supply well screened in the upper glacial aquifer and the shallow Magothy aquifer and 13 streamgages and 2 lake gages. The potentiometricsurface contours of the Magothy aquifer were interpreted from measurements at 88 wells (61 observation wells and 27 supply wells) screened in the middle to deep Magothy aquifer and the contiguous and hydraulically connected Jameco aquifer. The potentiometric-surface contours of the Lloyd aquifer were interpreted from measurements at 60 wells ( 55 observation wells and 5 supply wells) screened in the Lloyd aquifer and the contiguous and hydraulically connected North Shore aquifer. Many of the supply wells are in continuous operation and, therefore, were turned off for a minimum of 24 hours before measurements were made to allow the water levels in the wells to recover to ambient (nonpumping) conditions. Full recovery time at some of these supply wells can exceed 24 hours; therefore, water levels measured at these wells are assumed to be less accurate than those measured at observation wells, which are not pumped (Busciolano, 2002). In addition to pumping stresses, density differences (saline water) also lower the water levels measured in certain wells (Lusczynski, 1961). Recent water-quality data are lacking in these wells; therefore, a conversion to freshwater head could not be performed accurately and was not attempted. In this report, all water-level altitudes are referenced to the National Geodetic Vertical Datum of 1929 (NGVD 29).

The land surface altitude, or topography, was obtained from the National Oceanic and Atmospheric Administration (2016). The data were collected using light detection and ranging (lidar) and were used to produce a three-dimensional digital elevation model. The lidar data have a horizontal accuracy of 1.38 feet (ft) and a vertical accuracy of $0.40 \mathrm{ft}$ at a 95-percent confidence level for the "open terrain" land-cover category. The digital elevation model was developed jointly by the National Oceanic and Atmospheric Administration and the U.S. Geological Survey as part of the Disaster Relief Appropriations Act of 2013 (Pub.L. 113-2, H.R. 152, 127 Stat. 4). Land surface altitude is referenced to the North American Vertical Datum of 1988 (NAVD 88). On Long Island, NAVD 88 is approximately 1 foot higher than NGVD 29.

Hydrographs are included on these maps for selected wells that have continuous digital recording equipment, and each hydrograph includes the water level measured during the synoptic survey. These hydrographs are representative of the 2016 water year and show the changes throughout that period; a water year is the 12-month period from October 1 to September 30 and is designated by the year in which it ends. 


\section{Upper Glacial and Shallow Magothy Aquifers (Water Table)}

The upper glacial aquifer of Pleistocene age is the uppermost unit in the groundwater system of Long Island and contains the water table throughout the island, except in parts of central and eastern Nassau County and western Suffolk County where the entire upper glacial aquifer is unsaturated and the water table is in the shallow Magothy aquifer. The upper glacial aquifer was the principal source of water supply throughout Long Island for several decades, but contamination in many areas resulted in the widespread curtailment of its use for public supply. The general configuration of the water table forms an east-west mound that coincides with the topographic high (region of higher land surface altitude) and the glacial moraine along the center of the island with isolated areas of higher water levels in central Nassau County and in central Suffolk County. Local highs also are present in northwestern Nassau County (Stumm and others, 2002) and the central part of the southern peninsula (south fork) of eastern Suffolk County (Schubert and others, 2004). These areas of higher water levels are a result of the low hydraulic conductivity of the geologic units underlying these wells.

The water-table altitude on Long Island during April-May 2016 ranged from $0 \mathrm{ft}$ above NGVD 29 along the shore to more than $120 \mathrm{ft}$ above NGVD 29 in northwestern Nassau County. No measurements were collected in Kings County, 1 measurement of $16.91 \mathrm{ft}$ was collected in Queens County, 76 measurements ranging from 1.64 to $120.93 \mathrm{ft}$ were collected in Nassau County, and 199 measurements ranging from 1.51 to $75.36 \mathrm{ft}$ were collected in Suffolk County (all measurements were referenced to NGVD 29).

A geographic information system was used to create a continuous surface of the water table using an iterative finite difference interpolation technique with measurements from 275 observation wells, 1 supply well, 13 streamgages, 2 lake level gages, interpreted 10 -ft contour intervals, and the coastline (Esri, 2015). The approximate location of the regional groundwater divide for the water table was included on the map as a black dashed line which was drawn along the ridge of maximum water-table altitude.

\section{References Cited}

Busciolano, Ronald, 2002, Water-table and potentiometricsurface altitudes of the upper glacial, Magothy, and Lloyd aquifers on Long Island, New York, in March-April 2000, with a summary of hydrogeologic conditions: U.S. Geological Survey Water-Resources Investigations Report 01-4165, 17 p., 6 pls. [Also available at https://pubs.usgs.gov/ wri/2001/4165/wri20014165.pdf.]

Esri, 2015, ArcMap 10.4.1: Redlands, Calif., Esri, software. [Also available at http://desktop.arcgis.com/en/arcmap/10.4/ get-started/main/get-started-with-arcmap.htm.]
Finkelstein, J.S., and Como, M.D., 2018, Geospatial dataset of water-table and potentiometric-surface altitudes in the upper glacial, Magothy, and Lloyd aquifers of Long Island, New York, April-May 2016: U.S. Geological Survey data release, https://doi.org/10.5066/F7G15Z9T.

Lusczynski, N.J., 1961, Head and flow of ground water of variable density: Journal of Geophysical Research, v. 66 , no. 12, p. 4247-4256. [Also available at https://doi.org/10.1029/JZ066i012p04247.]

National Oceanic and Atmospheric Administration, 2016, NCEI Hurricane Sandy digital elevation models: National Centers for Environmental Information, digital data, accessed January 8, 2016, at https://www.ngdc.noaa.gov/ $\mathrm{mgg} /$ inundation/sandy/sandy_geoc.html.

Schubert, C.E., Bova, R.G., and Misut, P.E., 2004, Hydrogeologic framework of the North Fork and surrounding areas, Long Island, New York: U.S. Geological Survey WaterResources Investigations Report 2002-4284, 23 p., 4 pls., scale 1:120,000. [Also available at https://pubs.er.usgs.gov/ publication/wri024284.]

Smolensky, D.A., Buxton, H.T., and Shernoff, P.K., 1990, Hydrologic framework of Long Island, New York: U.S. Geological Survey Hydrologic Investigations Atlas HA-709, 3 sheets, scale 1:250,000. [Also available at https://pubs.er.usgs.gov/publication/ha709.]

Soren, Julian, 1971, Results of subsurface exploration in the mid-island area of western Suffolk County, Long Island, New York: Oakdale, N.Y., Suffolk County Water Authority, Long Island Resources Bulletin 1, $60 \mathrm{p}$.

Stumm, Frederick, 2001, Hydrogeology and extent of saltwater intrusion of the Great Neck peninsula, Great Neck, Long Island, New York: U.S. Geological Survey Water-Resources Investigations Report 99-4280, $41 \mathrm{p}$. [Also available at https://pubs.er.usgs.gov/publication/wri994280.]

Stumm, Frederick, Lange, A.D., and Candela, J.L., 2002, Hydrogeology and extent of saltwater intrusion on Manhasset Neck, Nassau County, New York: U.S. Geological Survey Water-Resources Investigations Report 00-4193, 42 p. [Also available at https://pubs.er.usgs.gov/publication/ wri004193.]

\section{Sheet 2-Potentiometric Surface in the Magothy and Jameco Aquifers}

The Magothy aquifer of upper Cretaceous age is the most extensive unit in the groundwater system of Long Island. This aquifer underlies most of Long Island and the offshore waters, except in parts of western and northern Kings and Queens Counties, northern Nassau County, and northwestern 
and northeastern Suffolk County, where it has been removed by erosion and glacial scour. The altitude of its upper surface ranges from more than 200 feet ( $\mathrm{ft}$ ) above the National Geodetic Vertical Datum of 1929 (NGVD 29) in parts of north-central Nassau County and west-central Suffolk County to more than $600 \mathrm{ft}$ below NGVD 29 in north-central Suffolk County (Smolensky and others, 1990). Aquifer thickness ranges from $0 \mathrm{ft}$ in northern and western Kings and Queens Counties, northern Nassau County, and parts of northern Suffolk County to more than $1,000 \mathrm{ft}$ in south-central Suffolk County (Soren and Simmons, 1987). The Magothy aquifer is the principal source of water supply in Nassau and Suffolk Counties.

This map depicts water levels during April-May 2016 in wells screened in the Magothy aquifer and the hydraulically connected Jameco aquifer. Most water-level measurements used to prepare this map (Finkelstein and Como, 2018) were made in wells screened near the middle of the aquifer and were supplemented by some measurements from the basal zone. Only a few water-level measurements made in the upper part of the aquifer were used. Because vertical hydraulic gradients in the Magothy aquifer can be large, measured potentiometric heads at a given location can vary depending on the depth of the well screen.

The general configuration of the potentiometric surface in the Magothy aquifer is similar to that of the water table, rising gradually from the western part of Long Island to form an east-west-trending mound in Nassau and western Suffolk Counties. The surface of the mound then gradually declines toward the eastern end of Long Island. In areas where deep channels have been eroded into the Magothy aquifer and filled with glacial deposits, the potentiometric-surface contours were drawn from water levels measured in wells screened in these upper glacial aquifer deposits, which are laterally contiguous and hydraulically connected to the Magothy aquifer. The inferred northern limit of the Magothy aquifer, the inferred extent of the Jameco aquifer, and the aquifer in which each well is screened are indicated on this map (Smolensky and others, 1990). Public-supply pumping and elevated chloride levels have lowered the potentiometric surface below NGVD 29 in southern Nassau County (Lusczynski and Swarzenski, 1966).

The altitude of the potentiometric surface in the Magothy aquifer on Long Island during April-May 2016 ranged from about $2 \mathrm{ft}$ below NGVD 29 in extreme southwestern Nassau County to more than $76 \mathrm{ft}$ above NGVD 29 in northeastern Nassau County. No measurements were collected in Kings and Queens Counties, 27 measurements ranging from -2.16 to $76.34 \mathrm{ft}$ were collected in Nassau County, and 61 measurements ranging from 3.31 to $72.87 \mathrm{ft}$ were collected in Suffolk County (all measurements were referenced to NGVD 29).

\section{References Cited}

Finkelstein, J.S., and Como, M.D., 2018, Geospatial dataset of water-table and potentiometric-surface altitudes in the upper glacial, Magothy, and Lloyd aquifers of Long Island, New York, April-May 2016: U.S. Geological Survey data release, https://doi.org/10.5066/F7G15Z9T.

Lusczynski, N.J., and Swarzenski, W.V., 1966, Salt-water encroachment in southern Nassau and southeastern Queens Counties, Long Island, New York: U.S. Geological Survey Water-Supply Paper 1613-F, 76 p. [Also available at https://pubs.er.usgs.gov/publication/wsp1613F]

Smolensky, D.A., Buxton, H.T., and Shernoff, P.K., 1990, Hydrologic framework of Long Island, New York: U.S. Geological Survey Hydrologic Investigations Atlas HA-709, 3 sheets, scale 1:250,000. [Also available at https://pubs.er.usgs.gov/publication/ha709.]

Soren, Julian, and Simmons, D.L., 1987, Thickness and hydrogeology of aquifers and confining units below the upper glacial aquifer on Long Island, New York: U.S. Geological Survey Water-Resources Investigations Report 86-4175, 3 sheets, scale 1:125,000. [Also available at https://pubs.er.usgs.gov/publication/wri864175.]

\section{Sheet 3-Potentiometric Surface in the Lloyd and North Shore Aquifers}

The Lloyd aquifer of upper Cretaceous age is the basal unit of the groundwater system of Long Island. This aquifer continuously underlies most of Long Island and the offshore waters, except in parts of northern and western Kings, Queens, and Nassau Counties and extreme northeastern Suffolk County where it has been removed by erosion. The upper surface of the aquifer ranges in altitude from less than 100 feet (ft) below the National Geodetic Vertical Datum of 1929 (NGVD 29) in extreme northern parts of Queens County to more than 1,500 ft below NGVD 29 in south-central Suffolk County (Smolensky and others, 1990). Aquifer thickness ranges from $0 \mathrm{ft}$ in northern and western Kings, Queens, and Nassau Counties and extreme northeastern Suffolk County to more than $500 \mathrm{ft}$ in extreme southeastern Nassau and southwestern Suffolk Counties (Soren and Simmons, 1987).

This map depicts water levels during April-May 2016 in 60 wells screened in the Lloyd and North Shore aquifers (Finkelstein and Como, 2018). Wells screened in the Pleistocene deposits of the North Shore aquifer in northern Nassau County 
are included because the North Shore aquifer is hydraulically connected to the Lloyd aquifer in these areas (Stumm, 2001; Stumm and others, 2002, 2004). The inferred northern extent of the Lloyd aquifer, the inferred extent of the North Shore aquifer, and the aquifer in which each well is screened are indicated on this map.

The general configuration of the potentiometric-surface altitude in the Lloyd aquifer is similar to those in the overlying water table and Magothy aquifers. The potentiometric surface gradually rises from the western part of Long Island to form an east-west-trending mound in eastern Nassau County that continues east into central Suffolk County. The mound then gradually declines toward the eastern end of Long Island. Public-supply and golf-course pumping has lowered the potentiometric surface in the Lloyd aquifer below NGVD 29 in northwestern Nassau County (Stumm and others, 2002).

The potentiometric-surface altitude in the Lloyd aquifer on Long Island during April-May 2016 ranged from about $9 \mathrm{ft}$ below NGVD 29 in northwestern Nassau County to more than $58 \mathrm{ft}$ above NGVD 29 in northeastern Nassau County. No measurements were collected in Kings County, 1 measurement of $7.51 \mathrm{ft}$ was collected in Queens County, 52 measurements ranging from $-8.81 \mathrm{ft}$ (North Shore aquifer) to $58.50 \mathrm{ft}$ were collected in Nassau County, and 7 measurements ranging from 14.10 to $35.60 \mathrm{ft}$ were collected in Suffolk County (all measurements were referenced to NGVD 29).

\section{References Cited}

Finkelstein, J.S., and Como, M.D., 2018, Geospatial dataset of water-table and potentiometric-surface altitudes in the upper glacial, Magothy, and Lloyd aquifers of Long Island, New York, April-May 2016: U.S. Geological Survey data release, https://doi.org/10.5066/F7G15Z9T.

Smolensky, D.A., Buxton, H.T., and Shernoff, P.K., 1990, Hydrologic framework of Long Island, New York: U.S. Geological Survey Hydrologic Investigations Atlas HA-709, 3 sheets, scale 1:250,000. [Also available at https://pubs.er.usgs.gov/publication/ha709.]

Soren, Julian, and Simmons, D.L., 1987, Thickness and hydrogeology of aquifers and confining units below the upper glacial aquifer on Long Island, New York: U.S. Geological Survey Water-Resources Investigations Report 86-4175, 3 sheets, scale 1:125,000. [Also available at https://pubs.er.usgs.gov/publication/wri864175.]

Stumm, Frederick, 2001, Hydrogeology and extent of saltwater intrusion of the Great Neck peninsula, Great Neck, Long Island, New York: U.S. Geological Survey Water-Resources Investigations Report 99-4280, 41 p. [Also available at https://pubs.er.usgs.gov/publication/wri994280.]
Stumm, Frederick, Lange, A.D., and Candela, J.L., 2002, Hydrogeology and extent of saltwater intrusion on Manhasset Neck, Nassau County, New York: U.S. Geological Survey Water-Resources Investigations Report 00-4193, 42 p. [Also available at https://pubs.er.usgs.gov/publication/ wri004193.]

Stumm, Frederick, Lange, A.D., and Candela, J.L., 2004, Hydrogeology and extent of saltwater intrusion in the northern part of the town of Oyster Bay, Nassau County, New York: U.S. Geological Survey Water-Resources Investigations Report 03-4288, 55 p. [Also available at https://pubs.er.usgs.gov/publication/wri034288.]

\section{Sheet 4-Depth to Water Table}

This map depicts the depth to the water table beneath Long Island during April-May 2016. Areas in which the depth to water table is shallow are shown in red and indicate areas where potential substructure flooding is more likely.

A geographic information system was used to create a continuous surface of the water table using an iterative finite difference interpolation technique with measurements from 275 observation wells, 1 supply well, 13 streamgages, 2 lake level gages, interpreted 10-foot (ft) contour intervals, and the coastline (Esri, 2015; Finkelstein and Como, 2018).

The land surface altitude, or topography, was obtained from the National Oceanic and Atmospheric Administration (2016). The data were collected using light detection and ranging (lidar) and were used to produce a high accuracy three-dimensional digital elevation model. The digital elevation model was developed jointly by the National Oceanic and Atmospheric Administration and the U.S. Geological Survey as part of the Disaster Relief Appropriations Act of 2013 (Pub.L. 113-2, H.R. 152, 127 Stat. 4). The datum for land surface altitude is the North American Vertical Datum of 1988 (NAVD 88). On Long Island, NAVD 88 is approximately 1 foot higher than the National Geodetic Vertical Datum of 1929 (NGVD 29). The continuous surface of the water table was adjusted for the vertical datum differences, NGVD 29 to NAVD 88, using a raster that reflects local variations in the datum shift across Long Island. This interpolated surface was then subtracted from the topography at the same location. The results are shown as a continuous depth to water table map. Field measurements of depth to water (accurate to a hundredth of a foot) are also plotted on the map.

The general configuration of the depth to the water table reflects the topography data; however, because the map scales of the topography $(1: 24,000)$ and water-table altitude $(1: 125,000)$ differ, the horizontal accuracy of the depth to water table is $1: 125,000$ with a vertical error of plus or minus 
$5 \mathrm{ft}$. Areas in which no water-level data were available for comparison are shown in gray; however, in areas along the south shore of Long Island, including marshes and the barrier island, the water-table altitude was assumed to be NGVD 29.

\section{Groundwater-Level Data Retrieval}

Groundwater-level data used to create this map product were obtained from the U.S. Geological Survey National Water Information System (NWIS) database (U.S. Geological Survey, 2017). The NWIS database consists of more than 875,000 records of wells, springs, test holes, tunnels, drains, and excavations in the United States. Available site information includes well-location and completion information, such as latitude, longitude, well depth, and aquifer. Water-level data from the NWIS database can be queried and used to construct historical time-series hydrographs for wells. As an example, for Suffolk County mapped well "S16783," go to the NWIS database (https://doi.org/10.5066/F7P55KJN) and click on "Site Information" on the main NWIS and site inventory pages. Then, click on the "Site Name" checkbox under "Site Identifier," and click "Submit." Enter "16783" in the "Site Name" field and choose the option button "match any part;" then click "Submit." A search will be completed, and a resulting list of site numbers will appear. In the "Site Number" column, click on the site number link, and then click on the "Field groundwater-level measurements" link. Use the dropdown menu beside "Available data for this site" and the links under "Output formats" to retrieve the desired data.

\section{References Cited}

Esri, 2015, ArcMap 10.4.1: Redlands, Calif., Esri, software. [Also available at http://desktop.arcgis.com/en/arcmap/10.4/ get-started/main/get-started-with-arcmap.htm.]

Finkelstein, J.S., and Como, M.D., 2018, Geospatial dataset of water-table and potentiometric-surface altitudes in the upper glacial, Magothy, and Lloyd aquifers of Long Island, New York, April-May 2016: U.S. Geological Survey data release, https://doi.org/10.5066/F7G15Z9T.

National Oceanic and Atmospheric Administration, 2016, NCEI Hurricane Sandy digital elevation models: National Centers for Environmental Information, digital data, accessed January 8, 2016, at https://www.ngdc.noaa.gov/ $\mathrm{mgg} /$ inundation/sandy/sandy_geoc.html.

U.S. Geological Survey, 2017, USGS water data for the Nation: U.S. Geological Survey data release, accessed August 18, 2017, at https://doi.org/10.5066/F7P55KJN. 
For more information about this report, contact:

Director, New York Water Science Center

U.S. Geological Survey

2045 Route 112, Building 4

Coram, NY 11727

dc_ny@usgs.gov

(518) 285-5602

Or visit our website at https://ny.water.usgs.gov

Publishing support provided by the

Pembroke, Reston, and Rolla Publishing Service Centers 


\section{$\mathbb{N}$}

咅

言

옹

言

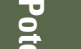

.

产

焉

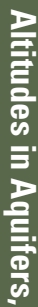

产

誉

$\frac{1}{2}$

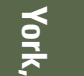

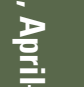

竝

㐱

S

商.

.

产.

㞼 